
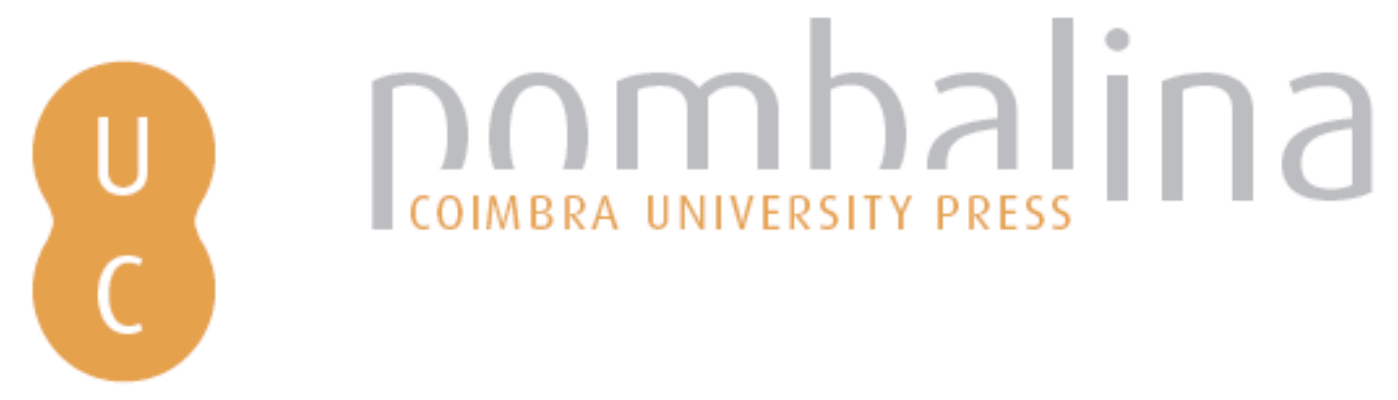

\title{
A poliorcética e o poder naval Bizantinos
}
Autor(es):
Nisa, João Rafael
Publicado por: Imprensa da Universidade de Coimbra
URL
persistente:
URI:http://hdl.handle.net/10316.2/40788
DOI:
DOI:https://doi.org/10.14195/978-989-26-1290-4_3

Accessed : $\quad$ 26-Apr-2023 15:23:33

A navegação consulta e descarregamento dos títulos inseridos nas Bibliotecas Digitais UC Digitalis, UC Pombalina e UC Impactum, pressupõem a aceitação plena e sem reservas dos Termos e Condições de Uso destas Bibliotecas Digitais, disponíveis em https://digitalis.uc.pt/pt-pt/termos.

Conforme exposto nos referidos Termos e Condições de Uso, o descarregamento de títulos de acesso restrito requer uma licença válida de autorização devendo o utilizador aceder ao(s) documento(s) a partir de um endereço de IP da instituição detentora da supramencionada licença.

Ao utilizador é apenas permitido o descarregamento para uso pessoal, pelo que o emprego do(s) título(s) descarregado(s) para outro fim, designadamente comercial, carece de autorização do respetivo autor ou editor da obra.

Na medida em que todas as obras da UC Digitalis se encontram protegidas pelo Código do Direito de Autor e Direitos Conexos e demais legislação aplicável, toda a cópia, parcial ou total, deste documento, nos casos em que é legalmente admitida, deverá conter ou fazer-se acompanhar por este aviso.

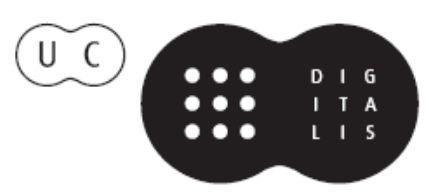


HISTÓRIA DE ROMA ANTIGA - VOLUME 3

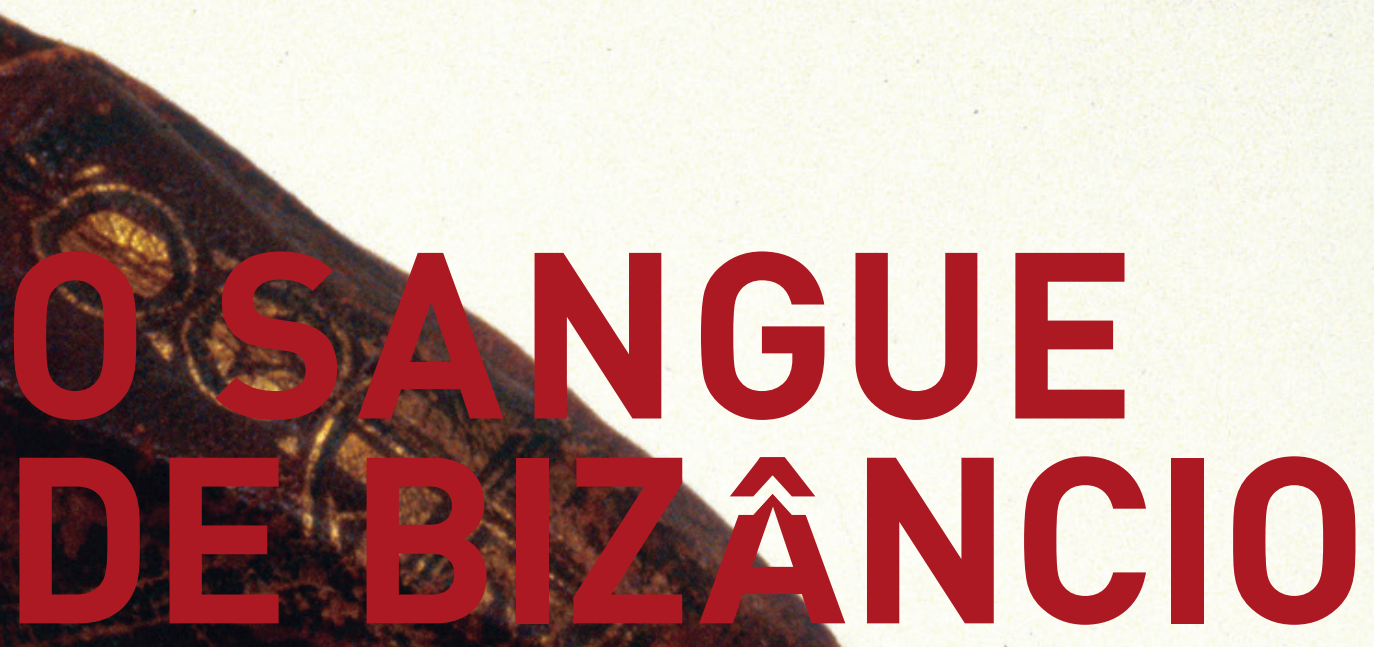

ASCENSÃO E QUEDA DO IMPÉRIO ROMANO DO ORIENTE

JOÃO GOUVEIA MONTEIRO DIR.

\section{GUSTTAVO GONÇALVES} JOÃO PAIVA DDRIGO GOMES O RAFAEL NISA 
III PARTE

\section{A POLIORCÉTICA E O PODER NAVAL BIZANTINOS}

por João Rafael Nisa 
(Página deixada propositadamente em branco). 


\section{ATORMENTAR A ALMA, DEMOLIR A VIRTUDE E DESTRUIR A PÓLIS - A POLIORCÉTICA BIZANTINA: ORIGENS, ORGANIZAÇÃO, TÁTICA E INOVAÇÃo}

\section{Introdução}

"Quando os homens saem do seu próprio país para encontrarem dificuldades e perigos em terras estrangeiras e lhes acontecem alguns desastres, em terra ou no mar, aos sobreviventes ainda lhes resta o seu solo nativo, a sua cidade e a sua pátria, de tal modo que não estão completamente destruídos" ${ }^{1}$. Assim começa Eneias, "o Tático", a sua obra sobre a poliorcética, isto é, sobre a arte de sitiar. O seu autor estaria longe de imaginar que o seu trabalho influenciaria estrategos, militares e políticos durante muitos séculos.

Neste capítulo, propomo-nos analisar a poliorcética bizantina em todas as suas vertentes. Contudo, e conforme realçou Salvatore Cosentino $^{2}$, existe uma linha ininterrupta que liga Eneias, "o Tático", ou mesmo Polieno, a numerosos estrategos bizantinos que escreveram entre os séculos vi e XI, numa continuidade que marca a diferença entre Bizâncio e o mundo medieval ocidental.

\footnotetext{
1 Jeffrey Henderson (ed.), Aeneas Tacticus, Asclepiodotus, Onasander, 192827. 2 Cosentino 200983.
} 
Aqui, não se produziu qualquer tratado versando a arte da guerra entre os inícios do século v e os finais do século xıI! Qual terá sido a razão para este facto?

Como veremos mais adiante, Bizâncio soube preservar e, em alguns casos, melhorar os manuais poliorcéticos herdados do mundo clássico. A sobrevivência do Império Romano do Oriente - romano na lei, grego na língua e cristão na religião - contribuiu, em grande parte, para a preservação deste saber. Analisaremos a poliorcética greco-romana de forma a que se perceba quais foram as suas invenções e de que modo é que elas podem ter influenciado a poliorcética bizantina; em segundo lugar, procederemos a uma descrição da organização e da tática bizantinas, no que concerne à guerra de cerco; seguidamente utilizaremos como fonte o tratado Parangelmata Poliorketica, atribuído a Héron de Bizâncio, para saber se a influência greco-romana é, de facto, palpável e se a poliorcética bizantina teve alguma evolução per se; finalmente, procuraremos contextualizar a fonte utilizada, para verificar se o ambiente político terá tido alguma influência na produção daquele manual de instruções destinado à construção de máquinas poliorcéticas.

As fontes impressas utilizadas são, na sua maioria, traduzidas do grego para o inglês. Foram ainda consultados vários estudos da especialidade, os quais se elencarão na bibliografia.

\section{As origens: a poliorcética greco-romana}

Desde o momento em que as populações começaram a concentrar-se no interior de estruturas defensivas que surgiram outros grupos que tentaram tomá-las. Se bem que existam referências ao uso de máquinas de cerco por parte dos Assírios, a verdade é que foi com os Gregos e com os Romanos que a poliorcética teve o seu maior desenvolvimento. 
Diodoro Sículo atribui a Péricles o primeiro uso, por parte de um grego, de um aríete, durante o cerco a Samos, em 440 a. C. Embora os Espartanos também tenham utilizado aríetes em Plateia, no ano de 429 a. C., a verdade é que os Gregos não prestaram grande atenção a este modo de fazer a guerra. Os primeiros grandes utilizadores e inovadores neste domínio, na bacia do Mediterrâneo, parecem ter sido os Cartagineses, que, em finais do século v a. C., utilizaram aríetes e torres de assalto contra algumas cidades gregas da Sicília. Este facto parece ter despertado a atenção de Dionísio I, o tirano de Siracusa que, em 399 a. C., já possuía um trem de cerco que englobava aríetes, torres de assalto e catapultas. Filipe II da Macedónia contava com engenheiros militares nas suas campanhas, sendo o mais importante Polídio da Tessália, que construiu uma helépolis (torre de assalto) de grandes dimensões para sitiar Bizâncio, em 340 a. C. Alexandre Magno, por seu turno, apenas conseguiu tomar Tiro, em 332 a. C., com o auxílio de Polídio, que se tornou conhecido como o "homem que tomou Tiro com Alexandre". Após o desmembramento do império de Alexandre, um dos reis helenísticos que mais viria a salientar-se no domínio da poliorcética foi Demétrio, cognominado "o Poliorcete"3 (daí a nossa palavra "poliorcética", para designar a arte de cercar castelos e praças-fortes). Plutarco descreve a admiração que as suas helepóleis, de grandes dimensões, causavam nos sitiados, e os habitantes da cidade de Rodes terão mesmo solicitado que, quando a guerra terminasse, lhes fosse cedido um dos engenhos de Demétrio, para que pudessem recordar o seu poder ${ }^{4}$.

O modo mais simples para tomar uma fortaleza passava pela transposição das muralhas com o auxílio de escadas, porém, este método tinha muitos riscos, deixando os soldados expostos aos

\footnotetext{
3 Duncan Campbell 2003 3-5.

4 Plutarco, Vies XIII: Démétrios - Antoine, 197739.
} 
arqueiros inimigos. As torres de assalto eram uma forma menos perigosa de uma força se acercar das muralhas, com o apoio de uma escada e de uma ponte móvel que permitia uma abordagem mais segura dos muros; outra das vantagens era permitir que se fizesse tiro com arco sobre os inimigos, a partir de um ponto mais elevado, e as torres de assalto utilizadas por Alexandre no cerco de Tiro teriam uma altura muito superior à das muralhas. Uma grande torre de assalto, helépolis ("a que toma cidades"), podia ter muitas variantes, sendo a mais conhecida a que foi concebida por Epímaco, a mando de Demétrio. Esta estrutura, que variava entre os vinte e nove e os quarenta e dois metros (consoante as fontes), encontrava-se protegida dos projéteis incendiários por várias placas de metal e estava subdividida em nove andares, aos quais se tinha acesso por duas escadas: uma para subir e outra para descer, de modo a evitar o congestionamento no interior da torre 5

Outro dos engenhos utilizados, que combinava o aríete e a torre de assalto, era a "tartaruga-aríete", e a mais célebre de todas foi a chamada "tartaruga-aríete de Hegetor", nome do engenheiro que terá desenhado esta estrutura de enormes dimensões, a mando de Demétrio, existindo a possibilidade de ter sido utilizada nos cercos de Salamina e de Rodes. Athenaeus Mechanicus afirmava que o seu aríete, de secção retangular, tinha $53,2 \mathrm{~m}$ de comprimento, com uma largura de $59 \mathrm{~cm}$ por $37 \mathrm{~cm}$ na cauda e $29,6 \mathrm{~cm}$ por 22,2 $\mathrm{cm}$ na ponta ${ }^{6}$; Vitrúvio, por sua vez, refere que o aríete "tinha um comprimento de cento e quatro pés, sendo a largura, em baixo, de um pé e um quarto, e a espessura de um pé; no topo, a largura tinha a contractura de um pé e a espessura a diminuição de três quartos de pé”, com “(...) um esporão de ferro duro, semelhante ao que costumam ter os barcos de guerra, a partir do qual se encontravam

\footnotetext{
5 Campbell 200310.

6 Cf. Campbell 2003 18-19.
} 
fixadas na madeira quatro chapas de ferro com cerca de quinze pés"'. Desconhece-se se terá existido verdadeiramente, uma vez que as suas dimensões e peso prejudicariam a respetiva mobilidade.

Quanto à artilharia primitiva, existiam dois tipos distintos: as máquinas sem torção e as máquinas de torção. O primeiro tipo, que também foi, cronologicamente, o que surgiu mais cedo, em inícios do século iv a. C., pode ser ilustrado com o gastraphétēs: este engenho tinha, em traços gerais, o mesmo princípio de funcionamento do arco compósito, com uma aparência similar à besta, e utilizava a força gerada pela tensão da corda para disparar um projétil com força considerável ${ }^{8}$; a sua complexidade e o facto de ser, eventualmente, de difícil manuseamento e lento no processo de recarregar, pode ter levado ao seu desaparecimento nos séculos seguintes, uma vez que não existem referências a este tipo de engenho no período romano. Pese embora esta situação, o gastraphétēs terá estado na génese das primeiras catapultas simples, sem mecanismo de torção, tendo-se generalizado o termo katapéltēs para designar todos os engenhos capazes de arremessar projéteis ${ }^{9}$; a partir de finais do século III a. C., as catapultas de torção começam a substituir os antigos engenhos sem torção. Sem nos querermos alongar sobre este assunto, há que referir que o aparecimento da catapulta, designada pelos autores gregos como lithóbolos ou petrobólos, alterou a forma de fazer a guerra, principalmente no que diz respeito aos cercos, uma vez que algumas destas máquinas podiam arremessar projéteis com pesos que variavam entre os quatro e os sessenta e cinco quilos, causando danos consideráveis nas muralhas ${ }^{10}$.

\footnotetext{
7 Vitrúvio, Tratado de Arquitectura, 2002395.

8 E. W. Marsden 1969 5-12.

9 E. W. Marsden 196915.

$10 \quad$ Campbell 200318.
} 
Quem mais beneficiou com a experiência e o domínio técnico dos Gregos foram os Romanos. Na verdade, as máquinas poliorcéticas assumiram um papel importante na ars romana de fazer a guerra, de tal modo que Vitrúvio e Vegécio lhes dedicam alguma atenção nos seus tratados. Enquanto Vitrúvio descreve os passos necessários para a construção de escorpiões e de balistas ${ }^{11}$, Vegécio enuncia os engenhos utilizados para defender a muralha: “(...) os sitiados costumam defender-se usando balistas, ónagros, escorpiões (...). A balista é armada por meio de cordas de tendões (...)" e se "(...) for manobrada por homens treinados que tenham ensaiado previamente o seu alcance, ela penetra onde quer que acerte. Já o ónagro (...) arremessa como se fosse um relâmpago. Não se encontra nenhum tipo de engenho de torção mais poderoso do que estes dois"12.

Utilizaremos os cercos mais relevantes da Guerra Judaica (66-73 d. C.) como paradigma da poliorcética romana, uma vez que neles foi aplicada uma panóplia de soluções, de natureza diversa. No decorrer do cerco a Jotapata, em 67 d. C., Vespasiano ordenou a construção de um aterro (adgestum), de modo a igualar a altura das muralhas, possibilitando a sua transposição pela infantaria. Flávio Josefo refere que "Vespasiano manda então posicionar concentricamente as suas máquinas de guerra perto do local - eram cento e sessenta - e deu ordens para que disparassem sobre os defensores da muralha. Com uma descarga tremenda, as catapultas dispararam dardos, as balistas lançaram pedras com um talento de peso, voaram virotes incendiários e uma nuvem de flechas"13. Os defensores, percebendo a intenção dos sitiantes, aumentaram o tamanho das muralhas, o que inviabilizou o plano do general romano; perante

\footnotetext{
11 Vitrúvio 2002 383-388.

12 Vegécio, Compêndio da Arte Militar, 2009355.

13 Flávio Josefo, A Guerra dos Judeus, 2007242.
} 
isto, "Vespasiano mandou avançar o 'carneiro'. Trata-se de uma trave gigantesca, como o mastro de um navio, com uma massa de ferro em forma de cabeça de carneiro na ponta - daí lhe vem o seu nome"14; desta feita, os Romanos conseguiram abrir uma brecha na muralha, mas, perante a resistência tenaz dos defensores, foram obrigados a retirar-se, situação que causou um redobrar de esforço por parte dos sitiantes, concentrados em levar a cabo o assalto final. Vespasiano ordena então que se aumente a altura do aterro e que se proceda à construção de três torres de assalto "cada uma com cinquenta pés de altura e inteiramente revestidas de placas de ferro para que o peso garantisse a sua estabilidade e fossem à prova de fogo" ${ }^{15}$. Na noite do quadragésimo sétimo dia de cerco, os Romanos conseguiram finalmente entrar na cidade e, segundo Flávio Josefo, "massacraram todos os que se mostraram"16.

Embora os Romanos tenham acabado por conquistar Jerusalém no ano de 70 d. C., os Judeus ainda tinham três fortalezas importantes em seu poder: Herodium (tomada em 71 d. C.), Machaerus (conquistada em 72 d. C.) e Massada. No final do ano de 73 d. C., o governador Lúcio Flávio Silva cercou esta última, colocou sentinelas nos locais que julgou adequados e construiu uma muralha de circunvalação para que os sitiados não escapassem. Contudo, existia um pormenor que não era de fácil resolução: a cidadela localizava-se no topo de um rochedo, pelo que era virtualmente inexpugnável. O general romano, após encontrar um local propício à construção de uma rampa, ordenou a edificação de "um sólido aterro com duzentos côvados de altura. Porém, sendo o aterro considerado pouco estável e amplo para a colocação de máquinas de guerra,

\footnotetext{
14 Flávio Josefo 2007246.

15 Flávio Josefo 2007251.

16 Flávio Josefo 2007 255. Sobre o assédio romano a Jotapata, veja-se também J. Gouveia Monteiro 2010 11-30.
} 
foi construída por cima dele uma plataforma de grandes pedras muito bem unidas, com cinquenta côvados de largura e outros tantos de altura"17. A rampa permitiu que os Romanos posicionassem uma torre de assalto, "inteiramente revestida a ferro", munida de escorpiões, de balistas e, possivelmente, de um aríete; os sitiados, por seu turno, tentaram contrariar as suas intenções, construindo uma muralha, atrás da primeira, com troncos de madeira, desenhada para amortecer o impacto dos aríetes (o que viria a verificar-se). Frustrado, Lúcio Flávio Silva "considerou ser mais fácil destruir esta muralha pelo fogo e ordenou aos seus soldados que lançassem sobre ela chuvas de projécteis incendiários"18; o fogo, auxiliado pelo vento, envolveu a muralha, o que lhes permitiu regressar ao seu acampamento, mas mantendo sempre uma apertada vigilância. No dia seguinte, lançaram-se ao assalto e encontraram a cidade envolvida num silêncio profundo. Flávio Josefo refere que os Romanos ficaram "incrédulos face a tão espantosa coragem (...) e em vez de se regozijarem sobre os seus inimigos, admiraram a nobreza da sua resolução e o desprezo pela morte demonstrado (...)"19.

Esta simbiose entre a astúcia, a inteligência e o conhecimento tecnológico ajudará a compreender o funcionamento da poliorcética bizantina, herdeira privilegiada do saber e da tradição da guerra de cerco greco-romana.

\section{A poliorcética bizantina: organização e tática}

Um dos aspetos mais relevantes da arte militar bizantina diz respeito à elevada importância que assumia a captura de fortalezas,

\footnotetext{
17 Flávio Josefo 2007462.

18 Flávio Josefo 2007462.

19 Flávio Josefo 2007469.
} 
um elemento crucial para o controlo de um vasto espaço geoestratégico. De facto, tal como na tática e na estratégia, a herança greco-romana é evidente e, se analisarmos os principais tratados versando a arte militar produzidos entre o século vil e o século XI, verificamos que grande parte da informação relativa à tomada de cidades e à instalação de cercos é, na sua grande maioria, uma repetição dos ensinamentos reproduzidos nos tratados de autores clássicos, como Apolodoro de Damasco, Biton de Alexandria ou Eneias, "o Tático".

No que diz respeito à organização da guerra de cerco, o exército bizantino recorria a forças regulares e a um corpo de engenheiros militares. Existiam ainda alguns povos que possuíam capacidades reconhecidas no domínio da construção civil e da carpintaria: os Isaurianos foram utilizados durante as campanhas de Belisário, em Itália, como tropas especializadas na guerra de cerco e na construção de fortificações. A falta de engenheiros militares durante uma campanha não prejudicava o sucesso da mesma, uma vez que o exército regular podia proceder a reparações básicas, todavia esta falha podia levar a situações complicadas, como aconteceu durante o cerco de Roma, em 546. Quando abandonaram a cidade, os Godos, sob o comando de Totila, destruíram algumas secções das muralhas, e Belisário, o grande general bizantino, conseguiu repará-las em 25 dias, mas a ausência de pessoal especializado levou a que fosse impossível consertar algumas portas a tempo da contraofensiva goda. A situação apenas se resolveu com a utilização de arqueiros e de tribuli $^{20}$.

O exército bizantino incorporava tropas com um nível de especialização mais elevado do que as restantes no que diz respeito à

\footnotetext{
20 Leif I. Petersen 2013 406-429. Os tribuli consistiam em estacas de madeira, aguçadas em ambas as extremidades, que estreitavam no meio de modo a permitir que fossem amarradas em conjunto, constituindo um importante meio de defesa de um campo fortificado (cf. Vegécio 2009 280-281).
} 
guerra de cerco, que eram designadas por technitai e assumiam a responsabilidade de construir e manobrar máquinas de cerco e de proceder à construção e reparação de fortificações; a sua destreza, particularmente na utilização de máquinas neurobalísticas, encontra-se bem documentada: no primeiro cerco de Roma, em 537, os Godos foram impedidos de se acercar das muralhas devido à precisão do tiro bizantino. Este tipo de unidades encontrava-se organizado segundo disposições legais, tendo Justiniano estabelecido que os ballistarii eram responsáveis pela construção, manutenção e armazenamento dos arsenais públicos (publica armamenta); eram pagos e recrutados como tropas regulares, sob jurisdição dos magistrados municipais (patres civitatum). $\mathrm{O}$ seu nome advém de uma das máquinas mais utilizadas pelos romanos, a ballista, o que sugere que este corpo era responsável pela supervisão e construção deste e de outro tipo de engenhos. Não se sabe ao certo como seria a sua organização em termos hierárquicos, embora seja seguro que tal existia: o arkhibalistários seria o responsável máximo, enquanto os ballistárioi mais experientes eram importantes no planeamento defensivo das cidades e na supervisão dos arsenais; os restantes, possivelmente designados pelo nome genérico de technítai, manobravam os engenhos de cerco, tais como os aríetes, as torres de assalto, os ónagros e as balistas ${ }^{21}$.

A partir de finais do século vi, com a introdução de novos engenhos como o trabuco de tração, surge um novo termo: o manganários. Embora tenha sido utilizado juntamente com a designação ballistários, começou a ser mais comum a partir do século viI; este modelo organizacional, que remontava ao reinado de Justiniano (527-565), pressupunha que os engenheiros militares agissem tanto como elementos defensivos como ofensivos. Em Nísibe, no ano de 573, os generais bizantinos atribuíram a responsabilidade da

$21 \quad$ Petersen 2013 115-119. 
construção de torres de assalto e de máquinas poliorcéticas a engenheiros especializados, enquanto as tropas regulares foram responsáveis pela construção de entrincheiramentos; em 630, após a guarnição persa da cidade de Edessa ter recusado a sua rendição, o exército bizantino utilizou o poder de fogo dos seus petrobólo $i$ para submeter a fortaleza ${ }^{22}$.

A população civil também tomava parte na guerra de cerco: quando uma fortaleza era cercada, a diferença entre civis e militares esbatia-se, participando todos na defesa da mesma. Devido à extensão de algumas muralhas, como no caso de Constantinopla, é provável que parte da população civil tivesse instrução para manobrar algumas máquinas de artilharia neurobalística, enquadrada por manganárioi; para além desta obrigação legal, também poderiam ser contratados para fazer a construção ou reparação de fortificações, em casos de emergência, procedendo-se ao recrutamento de artífices especializados (ferreiros, carpinteiros e pedreiros) ${ }^{23}$.

A guerra de cerco assumiu uma grande preponderância na estratégia bizantina, possivelmente devido à fraca densidade demográfica, que desencorajava as batalhas em campo aberto. Embora os reinados de Aleixo I ${ }^{24}$ e de Manuel I sejam uma exceção nesta matéria, para o período relativo ao reinado de João II Comneno (1118-1143) terão sido organizados aproximadamente vinte e cinco $\operatorname{cercos}^{25}$ !

Uma das novidades da poliorcética bizantina prende-se com a introdução e difusão (no Ocidente) do trabuco de tração, a partir do século VI, trazido do Oriente (possivelmente) pelos Ávaros. Apesar de menos elaborado, em termos tecnológicos, do que algumas

\footnotetext{
22 Petersen 2013 119-123.

23 Petersen 2013 139-147.

24 Do reinado de Aleixo I Comneno (1081-1118), há que referir o importante cerco de Niceia (1096), onde o exército bizantino participou, juntamente com as forças cruzadas, com cerca de 2000 homens de infantaria e máquinas de cerco. 25 John Birkenmeier 200286.
} 
máquinas de torção primitivas que vinham sendo utilizadas desde o período clássico, o trabuco de tração parece ter provocado uma escalada no nível de destruição causado pelas armas de cerco $^{26}$.

Os procedimentos habituais, que consistiam no cerco (ou bloqueio) e no assédio, continham muitas variáveis que dependiam de fatores tão diversos como o tamanho das forças, os recursos dos sitiados e dos sitiadores, a posição geográfica, a logística ou a capacidade técnica de um exército.

O bloqueio seria a tática mais utilizada, não implicando o assalto da fortificação (com ou sem máquinas de cerco), mas sim a privação de recursos essenciais, por parte de quem sitiava. A primeira fase passava por aniquilar a capacidade produtiva do inimigo, pilhando o gado e arrasando as colheitas das terras que se encontravam na envolvente de uma praça, impedindo o seu abastecimento. Esta situação, associada à destruição de edifícios e à perda de vidas humanas, demonstra bem a importância do fator psicológico na guerra de cerco: o elemento "medo", incutido na população, podia até levar a que uma determinada cidade nem sequer chegasse a ser sitiada, provocando a sua rendição e funcionando primordialmente como elemento dissuasor - os Persas utilizaram esta tática com bastante êxito na Síria, em 540, conseguindo mesmo alguns resgates avultados ${ }^{27}$. A construção de acampamentos fortificados ou de perímetros reforçados junto a uma cidade destinava-se a impedir a entrada ou a saída dos sitiados e a assegurar o controlo da área envolvente, através de razias e de pilhagens que prejudicavam o comércio, as comunicações e a atividade agrícola, privando a cidade dos recursos mais básicos; neste contexto, assume grande importância o controlo da água e dos recursos alimentares: embora a provisão de víveres, dentro das fortalezas, pudesse permitir uma

\footnotetext{
26 Petersen 2013 406-429.

$27 \quad$ Petersen 2013259.
} 
resistência de semanas ou mesmo de meses, a falta de água podia levar à rendição de uma força, a breve trecho, por isso a destruição de aquedutos era bastante frequente e era a maneira mais fácil de privar os defensores de água potável. Após a conquista de Cartago (em 533), por Belisário, os Bizantinos trataram de reparar as suas muralhas, rodeando-as com um fosso e uma paliçada; quando os Vândalos, liderados por Gelimero, tentaram recuperar o controlo da cidade, ficaram imóveis em frente à fortificação porque não possuíam os meios para a tomar, limitando-se a destruir o aqueduto, a bloquear as vias de acesso e a aguardar que algumas das forças auxiliares trazidas por Belisário acabassem por desertar ${ }^{28}$.

O último recurso será sempre a utilização de máquinas de cerco e o combate. Estas indicações são recorrentes nos tratados militares bizantinos produzidos em cronologias diversas, como o Strategikon (inícios do século viI) ou o Taktika (finais do século Ix ou inícios do século x). O Strategikon de Maurício adverte que a astúcia e a inteligência devem ser as qualidades primordiais de um general quando este procede ao cerco de uma cidade, e um dos exemplos fornecidos relaciona-se com a aparência física dos sitiantes, sugerindo-se que os soldados mais bem equipados se acerquem das muralhas para que os sitiados os consigam ver nitidamente, mantendo os que estão mais mal equipados longe do seu campo de visão, para que julguem que todas as unidades são de qualidade idêntica às que viram em primeiro lugar ${ }^{29} \ldots$ Esta vertente psicológica manifesta-se de outras formas, como nas condições de rendição de uma praça, devendo ser propostos termos razoáveis aos sitiados, como por exemplo a entrega de cavalos e de armas, pois se estes forem muito onerosos a defesa poderá tornar-se mais agressiva e o cerco mais duradouro, levando a um maior número de baixas e à utilização de

28 Giorgio Ravegnani 2009130.

29 George T. Dennis, Maurice's Strategikon, 1984106. 
mais recursos ${ }^{30}$. O tratado atribuído a Leão VI, intitulado Taktika, acrescenta a componente "medo" à equação; esta obra refere que os cercos conduzidos durante a noite causam um maior impacto nos sitiados, uma vez que a escuridão e a consequente falta de visibilidade provocam o pânico e a confusão, pois apenas se pode adivinhar quais os perigos que se avizinham. Perante este cenário, os sitiados tornar-se-ão mais propensos à rendição ${ }^{31}$.

As máquinas poliorcéticas, como as torres de assalto e os trabucos, só seriam utilizadas em último recurso ou quando uma parte da muralha se encontrava fragilizada. Para uma melhor aproximação à fortaleza, eram importantes as vineae (abrigos de madeira) ou as tartarugas móveis: estas últimas destinavam-se a proteger os sitiantes durante os importantes trabalhos de escavação das fundações dos muros; encontrando-se as galerias subterrâneas finalizadas e estando as paredes do túnel devidamente escoradas com o auxílio de barrotes de madeira, provocava-se a derrocada da torre ou do pano de muralha por intermédio do fogo. Estes engenhos foram descritos por alguns tratados militares bizantinos, pelo que iremos proceder a uma breve análise de um desses compêndios.

\section{A tradição e a inovação do texto de Héron de Bizâncio (ou Anónimo Bizantino)}

Um dos tratados mais importantes sobre a poliorcética bizantina é o intitulado Parangelmata Poliorketica, ou seja, um manual de instruções para construir máquinas de cerco.

Pouco ou nada sabemos sobre o autor deste texto, uma vez que nele não se encontra referido em parte alguma. A atribuição deste

\footnotetext{
30 Dennis 1984107.

31 George T. Dennis, The Taktika of Leo VI, 2014353.
} 
tratado, bem como do Geodesia, a Héron de Bizâncio deve-se a uma anotação acrescentada em período posterior, já no século XIV ou mesmo no século xv: uma vez que já se conheciam os tratados de Héron de Alexandria e de um matemático denominado Héron secundus, os primeiros editores que os publicaram apelidaram este autor de Héron tertius ${ }^{32}$. O manuscrito Vaticanus graecus 1605 foi datado paleograficamente como pertencendo ao século XI, embora alguns especialistas apontem como data mais provável o século $\mathrm{x}$, devido a várias considerações que o autor introduz no seu texto ${ }^{33}$.

A obra faz referência a tratados de autores clássicos que versam sobre a poliorcética, tais como Apolodoro de Damasco, Athenaeus Mechanicus, Biton, Fílon Mecânico e Héron de Alexandria. Ainda na introdução, explica que "existe a necessidade de utilizar máquinas para conduzir um cerco: diferentes tipos e formas de tartarugas, tais como as tartarugas para escavação, as tartarugas tapa-fossos, as tartarugas-aríete, as tartarugas com rodas na frente e as lâ̂sai blindadas, recentemente inventadas e muito leves, as tartarugas em forma de cunha para proteção contra pesados objetos rolantes, ou as tartarugas de vime; os tribuli com cinco pécheis de altura ${ }^{34}$; aríetes compósitos ou feitos de uma só peça de madeira; torres de madeira portáteis que são fáceis de obter; diferentes formatos de escadas, compósitas e muito leves; proteção contra objetos que são lançados de grandes alturas e contra chamas atiçadas pelos incendiários; escadas para observar o interior das cidades;

\footnotetext{
32 Alphonse Dain 1933 13-15.

33 Denis F. Sullivan, Siegecraft - Two Tenth-Century Instructional Manuals by "Heron of Byzantium", 2000 3-4.

34 Na tradução inglesa utilizou-se o termo "caltrop". Pensamos, contudo, que tanto o autor como o tradutor se referem aos pila muralia, referidos por Vegécio como tribuli (cf. Vegécio 2009 280-281); as dimensões apresentadas, cinco pécheis (aproximadamente $2,34 \mathrm{~m}$ ), parecem apontar nesse sentido. Mais adiante, o tratadista designa-os por labdáraiai e inclui-os na defesa contra objetos que podem ser arremessados pelos inimigos cujas cidades se localizam em pontos elevados (cf. Sullivan, op. cit., p. 37).
} 
diferentes ferramentas para minar diferentes tipos de muralhas; pontes para todo o tipo de fossos; máquinas para assaltar muralhas, sem escadas; máquinas de cerco para usar contra cidades costeiras; e pontes que permitem a passagem de um elevado número de homens, em boa ordem" ${ }^{35}$.

De todos os engenhos enunciados, importa tentar compreender o que terá sido, de facto, utilizado e o que não terá passado de um projeto. Enquadramos, neste último tipo, a "escada insuflável" e a "jangada de assalto". A "escada insuflável" é descrita como sendo aconselhável para agir, furtivamente, durante a noite, quando os sitiados não estão à espera e se encontram recolhidos nas suas casas: era constituída por várias peles de animais, cosidas umas às outras, utilizando gordura animal junto aos pontos, de modo a não perder ar, e com ganchos na extremidade para poder agarrar os merlões das fortalezas ${ }^{36}$. A "jangada de assalto", por seu turno, destinava-se a desembarques anfíbios (essencialmente em rios), tinha um formato quadrangular e podia estar equipada com uma rampa de desembarque ou com escadas ${ }^{37}$. Enquanto a "escada insuflável" terá a sua origem no trabalho de Fílon Mecânico, a "jangada de assalto" deriva essencialmente do trabalho de Apolodoro de Damasco e é, na opinião de P. H. Blyth, "um exercício interessante em geometria aplicada, mas com probabilidade de ser bastante instável" ${ }^{\text {38 }}$.

A utilização das máquinas descritas por Héron de Bizâncio encontra-se abonada em diversas fontes. O Taktika, de Leão VI, refere amplamente o uso de aríetes, de torres de assalto, de tartarugas para a escavação de fundações e de "máquinas que arremessam

\footnotetext{
35 Sullivan 200029.

36 Sullivan 200045.

37 Sullivan 2000 109-113.

38 P. H. Blyth 1992142.
} 
pedras e que se chamam alakátia ou tetraréai", destinadas a lançar projéteis e material inflamável para incendiar os telhados das habitações que se encontravam no interior da fortificação ${ }^{39}$. Nicéforo Ouranos também refere, na sua obra Taktika, que as muralhas têm de ser bombardeadas com pedras, por intermédio de trabucos, e que os aríetes devem tentar abrir uma brecha ${ }^{40}$. Leão, "o Diácono", na sua História, alude à utilização de máquinas nos cercos de Chandax, de Mopsuestia, de Tarso, de Antioquia e de Preslav. Durante o cerco de Arka, Nicéforo II Focas terá também utilizado máquinas de cerco para demolir as torres da fortaleza ${ }^{41}$, e tal facto leva-nos a crer que poderá ter empregado uma tartaruga-aríete ou uma torre de assalto com aríete, do tipo da helépolis. A referência é breve e pouco descritiva, mas a menção que lhes é feita nos tratados militares anteriormente citados torna possível esta interpretação; o que não parece tão verosímil é o ataque ser dirigido contra uma das torres e não contra as muralhas, uma vez que as torres, em princípio, são mais fortemente guarnecidas dos que os panos de muralha.

Héron de Bizâncio descreve ainda a utilização do fogo greguês através da sua projeção com o auxílio de um tubo. Embora já se encontrem referências ao seu emprego no tratado de Leão $\mathrm{VI}^{42}$, o autor atribui-lhe elevada importância no abatimento do moral do inimigo, favorecendo o abandono dos postos de defesa e da vigilância, por parte deste ${ }^{43}$. Curiosamente, no desenho onde ilustra a sua aplicação, observamos que o operador dirige o fogo greguês contra uma fortificação e não, como era mais comum, contra uma

\footnotetext{
39 Dennis 2014363.

$40 \quad$ Eric McGeer 2008 159-161.

41 Alice-Mary Talbot e Denis F. Sullivan, The History of Leo the Deacon, 2005122.

42 "Estes são chamados sifões manuais e foram fabricados recentemente por Sua Majestade", cf. Dennis, Taktika, 2014529.

43 Sullivan 200099.
} 
embarcação: as especificidades deste composto químico levaram a que a sua utilização se focasse mais na guerra do mar, pois a madeira, ao contrário da pedra, é um bom condutor do fogo.

Julgamos relevante enunciar as razões pelas quais o autor foi levado a compor este manual. A resposta parece estar no final da obra Parangelmata Poliorketica, onde argumenta que "se os comandantes do exército completarem cuidadosamente, com lógica e diligência contínua, estas máquinas de cerco (...) facilmente

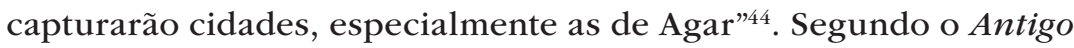
Testamento, Agar era mãe de Ismael e, no período que analisamos, era uma das expressões utilizadas pelos Bizantinos para designar o povo árabe.

\section{Conclusão}

Como pudemos verificar, a poliorcética bizantina congrega em si conhecimentos bastante variados. O seu mérito consiste no aproveitamento dos ensinamentos dos engenheiros clássicos e no seu aperfeiçoamento e aplicação. Mas os Romanos do Oriente foram ainda mais além: tiveram a capacidade de aproveitar as inovações tecnológicas trazidas pelos seus inimigos, como no caso da adoção do trabuco de tração, ou de desenvolver armamento próprio que viria a diferenciá-los dos demais e que ainda hoje reconhecemos como sendo da sua autoria; referimo-nos, concretamente, ao chamado fogo greguês. Os diversos tratados produzidos, versando a arte militar entre os séculos $\mathrm{x}$-xI, parecem corresponder a uma intensificação das campanhas militares e, sobretudo, ao aparecimento de um inimigo, os Árabes, que não eram inferiores aos Bizantinos em termos de conhecimento científico-tecnológico.

44 Sullivan 2000113. 
Se bem que as fontes descrevam o uso de máquinas, particularmente torres de assalto, aríetes e trabucos, a verdade é que este tipo de engenhos parece ter sido utilizado numa segunda fase, quando falhavam as negociações para a rendição de uma fortaleza ou quando se esgotavam todos os recursos dissuasores que se encontravam à disposição dos generais bizantinos (p. ex.: privação de bens essenciais, especialmente de água).

Importa ainda referir que, se bem que a guerra de cerco pudesse ser bastante dispendiosa, a verdade é que esse modo de fazer a guerra parece ter tido mais acolhimento do que as batalhas campais. Para a construção das máquinas eram necessários técnicos especializados e materiais que por vezes rareavam (ou eram totalmente inexistentes) nas regiões por onde os exércitos se encontravam em campanha, mas, tal como referimos, algumas vezes encontraram-se soluções (como o transporte marítimo) para contornar este problema. Na nossa opinião, esta preferência pela guerra de cerco poderá ter três explicações fundamentais: a primeira de ordem demográfica, uma vez que os exércitos em campanha não eram muito numerosos, tendo em conta a necessidade de defender as fronteiras; a segunda relaciona-se com o domínio geoestratégico que as fortalezas permitiam, pois as batalhas campais poderiam não ter um desfecho favorável e constituir uma sangria de homens e de dinheiro; em terceiro lugar, mas de capital importância, devido à superioridade tecnológica que os Bizantinos tinham sobre a maioria dos seus inimigos (Búlgaros, Russos, Sérvios...), com exceção dos Árabes. 
(Página deixada propositadamente em branco). 


\section{O DRÓMŌN COMO ELEMENTO DE AFIRMAÇÃO DO PODER NAVAL BIZANTINO NO MEDITERRÂNEO} (C. 875-1025)

Drómōn, palavra grega que deriva de drómos ("velocidade"), é o termo que designa o navio de guerra bizantino, sucessor da triérēs grega e da liburna romana. As primeiras referências a este tipo de embarcação datam do século v d. C., mas apenas a partir do século vi d. C. começa a ser mencionado com frequência nas fontes. Não subsistem dúvidas de que a palavra drómōn passou a ser utilizada para denominar os navios de guerra bizantinos em geral ou, pelo menos, alguns deles, visto que este tipo de embarcação é descrito como sendo muito mais veloz do que uma liburna tradicional do Baixo Império ${ }^{45}$.

Após a queda do Império Romano do Ocidente, Bizâncio soube fazer valer a sua supremacia no mar. Em 508, uma frota composta por mais de 100 navios de guerra, transportando cerca de 8000 homens, recebeu ordens de Anastácio I para devastar a costa da Calábria e da Apúlia, de modo a desestabilizar os territórios dominados por Teodorico, o grande rei dos Ostrogodos ${ }^{46}$. Os primeiros drómōnes

\footnotetext{
45 John H. Pryor e Elizabeth M. Jeffreys 2006125.

46 Ravegnani 2009 178-179.
} 
eram navios com uma só fileira de remos, encontrando-se os remadores protegidos sob o convés; as suas dimensões seriam reduzidas, quando comparadas com as birremes e trirremes greco-romanas, suas predecessoras. Constantino I terá derrotado Licínio, em 324, na batalha de Dardanelos, utilizando com sucesso unirremes contra as birremes e as trirremes que o seu adversário havia trazido para o combate. Porém, o termo drómōn não foi utilizado somente para designar navios com uma só fileira de remos, uma vez que no século x existiam birremes às quais se chamavam, também, drómōnes.

Em meados do século viI, o poder naval bizantino, até então incontestado, fica abalado devido à ação dos governadores muçulmanos da Síria e do Egito, que começam a construir frotas e a perpetrar ataques contra Chipre, Rodes e a Sicília. No ano de 655, os muçulmanos causam o primeiro grande revés à marinha bizantina, derrotando-a perto de Phoinikoûs (Liceia) e aniquilando a sua armada, tendo o imperador Constâncio II escapado, por pouco, ao desastre. Esta batalha abriu as portas do Mediterrâneo oriental à marinha muçulmana e, como resposta, foi criada uma nova frota bizantina (karabisiánoi), sedeada em Samos, para tentar conter esta ameaça ${ }^{47}$.

A conquista de Cartago e a invasão da Península Ibérica, em 711, aumentaram a influência do poder naval muçulmano, dotando a sua marinha de importantes pontos de apoio na costa, essenciais para o abastecimento e a reparação de navios; a partir deste momento, a marinha bizantina começou a restringir a sua ação ao Mediterrâneo oriental, tendo como limite, a ocidente, a Península Itálica e ilhas adjacentes; em 715, a Anatólia foi invadida por forças muçulmanas, que viriam a alcançar Constantinopla, em 717. Pouco depois, a frota dos karabisiánoi seria dissolvida, dando origem a dois comandos navais: a frota imperial (basilikòn plóimon),

47 Pryor e Jeffreys 200625. 
com base em Constantinopla, e a frota thematiká (kibyrrhaioti), com base em Antalya.

Durante as décadas seguintes, os muçulmanos continuaram a empreender a conquista de possessões bizantinas no Mediterrâneo. No ano de 827, iniciaram a conquista da Sicília (completada em 878) e, em 868, ocuparam Malta. Este período corresponde ao auge do poder muçulmano, alicerçado no elevado número de armadas muçulmanas que patrulhavam o Mediterrâneo e no domínio de pontos-chave, de elevada importância estratégica, como as ilhas de Creta, Malta e Chipre.

Em finais do século Ix, a corte de Constantinopla começou a dar maior importância às questões relacionadas com a guerra no mar. O tratado militar intitulado Taktika, escrito (ou mandado escrever) pelo basileús Leão VI (886-912), é o primeiro tratado militar bizantino a realçar a importância da guerra naval, estipulando um elenco variado de diretrizes: a construção de castelos de madeira, nos navios, para que pudessem servir como plataforma elevada de tiro; a utilização de vários tipos de drómōnes, incluindo alguns de menor dimensão, mais velozes e especialmente indicados para operações onde a rapidez era crucial. Leão VI estabeleceu um modelo organizacional, onde pequenos grupos de navios (três a cinco) deveriam operar como uma unidade, sob o comando de um oficial superior; aconselhava ainda o arremesso de esferas de madeira inflamáveis e, por fim, o uso de uma substância líquida, projetada por intermédio de um sifão: o famoso fogo greguês ${ }^{48}$. A utilização deste engenho encontra-se atestada desde o ano de 678, data em que uma frota muçulmana que bloqueava Constantinopla havia seis anos foi atacada por uma frota bizantina que já fazia uso desta arma; embora se desconheçam as suas origens, a tradição atribui a sua invenção a Calínico de Heliópolis, um cientista natural

48 Dennis, Taktika, 2014 502-535. 
da Síria. Especula-se que da sua composição fizessem parte nafta (proveniente da zona do mar Negro e já conhecida na Antiguidade Clássica), misturada com resina ou cera, enxofre, cal, terebintina e nitrato de potássio, de modo a criar uma substância inflamável que pudesse ser projetada contra as embarcações inimigas através de um siphōn, que se encontrava colocado na proa, devidamente protegido; contudo, Leão VI refere que podiam ser utilizados dois sifões manuais (cheirosíphōna) adicionais em ambos os lados do navio, a fim de repelir os ataques laterais. Construído em bronze, o sifão projetava o líquido inflamável (que se encontrava armazenado num tanque selado) através de uma bomba manual que, devido à pressão existente no tanque, era incendiada por intermédio de uma lamparina aplicada na extremidade do sifão.

Tanto os Bizantinos como os muçulmanos utilizavam projéteis incendiários lançados por arcos, por catapultas e por outros engenhos neurobalísticos, mas, por volta do ano de 835 , começa a navegar no Mediterrâneo a harraqa, um navio muçulmano, também ele equipado com um sistema que permitia a utilização do fogo greguês. Agora que ambos os lados empregavam este tipo de arma, os Bizantinos começaram a evitar o combate contra as harraqat, uma vez que as batalhas poderiam ter desfechos muito adversos (ou ser meras vitórias de Pirro), aumentando consideravelmente a perda de meios humanos e materiais.

Durante o período que engloba a perda e a reconquista de Creta, que se caracteriza por uma grande expansão do império e pelo restabelecimento das suas antigas fronteiras, a pacificação do mar Egeu e a manutenção das comunicações com o Ocidente constituem os principais objetivos da política bizantina ${ }^{49}$. Esta situação dependia, primordialmente, além da reconquista de Creta, da consolidação da presença bizantina na Itália, o que levou à construção de uma frota

49 Hélène Ahrweiler, 1966 111-112. 
de grande magnitude, de natureza puramente ofensiva, que viria a ser responsável pela erradicação da pirataria existente no mar Egeu e na Sicília, bem como pela preparação das investidas contra a ilha (uma importante plataforma que permitia levar a cabo grandes operações terrestres contra a Síria); após sucessivas tentativas para a tomar, Romano II (959-963) ordena a construção de uma grande esquadra, com um único objetivo: a sua conquista. A conjugação das melhores tropas dos tágmata e do poder naval bizantino permitiu que estivessem reunidas as condições para que o império passasse ao ataque; Leão, "o Diácono", refere que a esquadra que Nicéforo Focas (963-969) utilizou nesta operação vitoriosa (960-961) incluía navios que lançavam fogo (birremes e trirremes) e navios de transporte que carregavam pranchas de madeira, que viriam a permitir um rápido desembarque na praia, para surpresa dos inimigos ${ }^{50}$. A força naval utilizada nesta operação seria constituída por 1000 drómōnes de natureza diversa, 200 drómōnes equipados com sifão e 317 navios de transporte ${ }^{51}$.

Após o sucesso obtido com a reconquista de Creta, a esquadra que havia sido construída para esse fim viria a ser utilizada para submeter, no ano de 965, a ilha de Chipre, região onde o poder bizantino nunca tinha sido efetivo. Com o domínio destes dois territórios de grande importância geoestratégica e com a consequente pacificação da bacia oriental do Mediterrâneo, a marinha bizantina pôde então virar as suas atenções para ocidente. Nesse sentido, foram realizadas diversas operações, sem grande sucesso, contra os muçulmanos da Sicília (964-967) e contra Otão da Germânia, que ameaçava as possessões bizantinas na Apúlia e na Calábria. Abre-se aqui um novo período na afirmação do poder naval de Bizâncio, em que os grandes objetivos passam pelo restabelecimento do poder imperial em Itália,

50 Talbot e Sullivan, The History of Leo the Deacon, 2005 60-61.

$51 \quad$ Ahrweiler 1966114. 
muito afetado pelas revoltas instigadas pelas fações locais, e pela reconquista da Sicília, que continuava nas mãos dos muçulmanos.

Tal como foi explicado na segunda parte desta obra, as guerras contra os muçulmanos, no Oriente, e contra os Russos e os Búlgaros, nos Balcãs, com a intervenção quase exclusiva do exército terrestre, absorverão as atenções bizantinas entre finais do século $\mathrm{x}$ e inícios do século $\mathrm{xI}$, o que levará a que a marinha de guerra seja remetida para uma posição operacional secundária. Além disso, a conquista de Creta e a consolidação do poder bizantino no sul de Itália farão com que o seu papel se resuma à manutenção das comunicações e ao patrulhamento das águas territoriais, assistindo-se, assim, a um período em que não haverá necessidade de manter uma grande frota, de caráter permanente. Se, por um lado, a pacificação dos mares e a relativa acalmia propiciavam a diminuição da frota de guerra, por outro incentivavam o aumento da frota mercantil, fruto da segurança gerada pela erradicação dos focos de instabilidade no Mediterrâneo oriental.

A paz marítima e a segurança da navegação não se devem apenas às vitórias obtidas, mas também ao enfraquecimento do poder naval dos Árabes da Cilícia e da Síria. Desta forma, o Império Bizantino negligenciará a frota de drómōnes, que tinha a capacidade de proteger as rotas do comércio marítimo e de erradicar os inimigos que as ameaçassem, mas que, devido ao período de paz que se atravessava, se considerava desnecessária; a estratégia passará então pela criação de frotas provinciais, em número reduzido, e pelo abandono dos grandes navios que compunham a frota imperial ${ }^{52}$. O enfraquecimento do poder marítimo não permitirá consolidar a relativa vantagem obtida através das vitórias terrestres, o que, em conjugação com o aparecimento de novos inimigos, como por exemplo os Normandos, pôs em risco a sobrevivência da própria pólis outrora fundada por Constantino.

$52 \quad$ Ahrweiler 1966117. 


\section{Bibliografia}

\section{Fontes}

Dennis, George T. (1984), Maurice's Strategikon - Handbook of Byzantine Military Strategy. Philadelphia, University of Pennsylvania Press.

Dennis, George T. (2014), The Taktika of Leo VI. Revised Edition. Edição bilingue. Washington, Dumbarton Oaks.

Flávio Josefo (2007), A Guerra dos Judeus. História da Guerra entre Judeus e Romanos. Tradução de Miguel Mata (a partir de uma edição inglesa). Apresentação de Moisés Espírito Santo. Lisboa, Edições Sílabo.

Henderson, Jeffrey (ed.) (1928), Aeneas Tacticus, Asclepiodotus, Onasander. Harvard University Press, Loeb Classical Library.

McGeer, Eric (2008), Sowing the Dragon's teeth: Byzantine Warfare in the Tenth Century. Edição bilingue que contém os tratados Praecepta Militaria, de Nicéforo Focas, e Taktika, de Nicéforo Ouranos. Dumbarton Oaks Studies, XXXIII, Washington, Dumbarton Oaks.

Plutarco (1977), Vies XIII: Démétrios - Antoine. Tradução de Robert Flacelière e Émile Chambry. Edição bilingue. Paris, Société d'Édition "Les Belles Lettres". Sullivan, Denis F. (2000), Siegecraft - Two Tenth-Century Instructional Manuals by "Heron of Byzantium". Edição bilingue. Dumbarton Oaks Studies XXXVI, Washington, Dumbarton Oaks.

Talbot, Alice-Mary / Sullivan, Denis F. (2005), The History of Leo the Deacon. Introduction, translation and annotations by Alice-Mary Talbot and Denis F. Sullivan. Dumbarton Oaks Studies XLI, Washington, Dumbarton Oaks. Vegécio (2009), Compêndio da Arte Militar. Tradução de João Gouveia Monteiro e José Eduardo Braga. Estudo Introdutório, comentários e notas de João Gouveia Monteiro. Edição bilingue. Prefácio de Maria Helena da Rocha Pereira. Coimbra, Imprensa da Universidade de Coimbra.

Vitrúvio (2002), Tratado de Arquitectura. Tradução do Latim, introdução e notas por Manuel Justino Maciel. Ilustrações de Thomas Noble Howe. Lisboa, IST Press. 


\section{Estudos}

Ahrweiler, Hélène (1966), Byzance et la mer: la marine de guerre, la politique et les institutions maritimes de Byzance aux VIIe-XVe siècles. Paris, Presses Universitaires de France.

Birkenmeier (2002), John, The Development of the Komnenian Army: 1081-1180. History of Warfare, vol. 5. Leiden-Boston-Colónia, Brill.

Blyth, P. H. (1992), "Apollodorus of Damascus and the Poliorcetica"; in Greek, Roman and Byzantine Studies, 33. Durham, Duke University, pp. 127-158.

Campbell, Duncan (2003), Greek and Roman Artillery, 399 BC-AD 363. Oxford, Osprey Publishing.

Campbell, Duncan (2003), Greek and Roman Siege Machinery, 399 BC-AD 363. Oxford, Osprey Publishing.

Cosentino, Salvatore (2009), "Writing about War in Byzantium"; in Revista de História das Ideias, vol. 30. Coimbra, Faculdade de Letras da Universidade de Coimbra, pp. 83-99.

Dain, Alphonse (1933), La Tradition du Texte d'Héron de Byzance. Paris, Société d'Édition "Les Belles Lettres".

Haldon, John (2008), The Byzantine Wars. Stroud, The History Press.

Marsden, E. W. (1969), Greek and Roman Artillery. Historical Development. Oxford, Clarendon Press.

Monteiro, João Gouveia (2010), "Flávio Josefo e o cerco romano a Jotapata (67 d. C.)”, in J. G. Monteiro, Entre Romanos, Cruzados e Ordens Militares, Lousã, Salamandra, pp. 11-30.

Ostrogorsky, George (1984), History of the Byzantine State. Tradução inglesa (de Joan Hussey). Padstow, Basil Blackwell.

Petersen, Leif (2013), Siege Warfare and Military Organization in the Successor States (400-800 AD) - Byzantium, the West and Islam. History of Warfare, vol. 91. Leiden-Boston, Brill.

Pryor, John H. e Jeffreys, Elizabeth M. (2006), The Age of the Dromon: The Byzantine Navy ca 500-1204, Leiden-Boston, Brill.

Ravegnani, Giorgio (2006), Introduzione alla storia bizantina. Bolonha, Il Mulino, 2006. Ravegnani, Giorgio (2009), Soldati e guerre a Bisanzio. Bolonha, Il Mulino. 